\title{
Immunochemical Localization of Integrin Subunits in the Human Placenta
}

\author{
Mamoru Isemura*, Takashi Kazama $\dagger$, Kuni Takahashi $\ddagger$ \\ and Yu Yamaguchi§ \\ Department of Food and Nutritional Sciences, University of \\ Shizuoka, Shizuoka 422, †Department of Dermatology, \\ Nïgata University School of Medicine, Niigata 951, \\ $\$$ Takeyama Hospital, Niigata 951, and §Department of \\ Obstetrics and Gynecology, Tohoku University School of \\ Medicine, Sendai 980
}

\begin{abstract}
Isemura, M., Kazama, T., Takahashi, K. and Yamaguchi, Y. Immunochemical Localization of Integrin Subunits in the Human Placenta. Tohoku J. Exp. Med., 171 (2), 167-183 — Localization of integrins in the human placenta was examined in comparison with those of fibronectin and laminin. In the early chorionic villi, the $\alpha 5$ and $\beta 1$ subunits were localized on the basal surface of villous cytotrophoblastic cells, while the $\alpha 6$ and $\beta 4$ subunits were distributed around the entire surface of the cytotrophoblastic cells, suggesting that these cells attach to fibronectin rather than laminin on the epithelial basement membrane. In the term placenta, the $\alpha 5$ subunit was not detected on the epithelial cells, but the $\beta 6$ and $\beta 4$ subunits were detected on the basal surface of syncytiotrophoblastic cells, suggesting that these cells make use of $\alpha 6 \beta 4$ integrin to attach to the trophoblastic basement membrane. These results suggest that cells utilize the specific receptor for their attachment in correspondence to the extracellular matrix component to which they attach.— fibronectin; laminin; integrin; placenta; cell adhesion
\end{abstract}

Cell adhesion molecules including fibronectin (FN) and laminin (LN) are believed to have an important role in cell differentiation, tissue morphogenesis and tissue organization (Hynes 1981; Martin and Timpl 1987; Ruoslahti 1988). We have previously reported the localization of these extracellular matrix components in the human placenta (Kurosawa et al. 1985; Yamaguchi et al. 1985; Yamada et al. 1987). One of the most interesting findings has been that the localization of FN changes as the tissue matures (Kurosawa et al. 1985; Yamaguchi et al. 1985; Yamada et al. 1987). Therefore, it should be interesting to know changes in the distribution of the cellular receptors for these molecules called

Received July 29, 1993; revision accepted for publication September 13, 1993.

*To whom correspondence should be addressed.

$\S$ Present address : La Jolla Cancer Research Foundation, La Jolla, California 92037; USA. 
integrins (Hynes 1987; Ruoslahti 1988; Springer 1990).

Each integrin molecule comprises an $\alpha$ and a $\beta$ subunit and there are three major subfamilies containing one of the $\beta 1, \beta 2$ and $\beta 3$ subunits. The $\beta 1$ integrin subfamily includes receptors that bind to the extracellular matrix component ligands FN, LN and collagen. The ligands for $\beta 1$ integrins are as follows: integrins $\alpha 1 \beta 1$ and $\alpha 2 \beta 1$, LN and collagen; $\alpha 3 \beta 1, \mathrm{FN}, \mathrm{LN}$ and collagen; $\alpha 4 \beta 1$, $\mathrm{FN} ; \alpha 5 \beta 1, \mathrm{FN} ; \alpha 6 \beta 1$, LN (Springer 1990). Recently $\alpha 6 \beta 4$ integrin has been proposed to be one of the receptors for LN (Lee et al. 1992).

In the present work, we examined the immunohistochemical localization of various integrin subunits $(\alpha 1-\alpha 6, \beta 1$ and $\beta 4)$ in relation to the basement membrane components FN and LN in the chorionic villi of the placentas at early and late gestations.

\section{Materials ANd Methods}

Tissue specimens. Human first-trimester chorionic villi from pregnancies terminated by legal abortion and term placentas from uncomplicated pregnancies were obtained as described previously (Kurosawa et al. 1985; Yamaguchi et al. 1985; Yamada et al. 1987).

Antibodies. Rabbit anti-FN antiserum and anti-LN anti-serum were those described previously (Kurosawa et al. 1985; Yamaguchi et al. 1985; Yamada et al. 1987). Mouse monoclonal antibodies against the integrin $\alpha 2, \alpha 4, \alpha 5$ and $\alpha 6$ subunits were from Immunotech Inc., Marseilles, France and those against $\alpha 1, \alpha 3, \beta 1$ and $\beta 4$ subunits were from T Cell Sciences Inc., Cambridge, Chemicon International Inc., Temecula, Iwaki Glass Inc., Tokyo and Telios Pharmaceuticals Inc., San Diego, respectively.

Staining procedures. For immunoperoxidase staining of FN and LN, tissue sections of $4 \mu \mathrm{m}$ were fixed in formalin and treated according to the methods described previously (Yamada et al. 1987). For immunofluorescence staining of integrin subunits, the cryostat sections were incubated with monoclonal antibodies and fluorescein isothiocyanateconjugated rabbit anti-mouse immunoglobulin G (DAKO Japan Co. Ltd., Tokyo) as described previously (Kurosawa et al. 1985; Yamaguchi et al. 1985). The control sections were incubated with phosphate-buffered saline instead of monoclonal antibodies.

\section{Results}

\section{Localization of $F N$ and $L N$}

Immunofluorescence localization revealed that FN and $\mathrm{LN}$ were present on the epithelial and endothelial basement membranes of the premature placenta and in their connective tissue core, while FN was scarcely detected on the epithelial basement membrane of the mature placenta (data not shown) as has been reported (Kurosawa et al. 1985; Yamaguchi et al. 1985; Yamada et al. 1987).

Immunoperoxidase localization of these molecules (Fig. 1) confirmed the observation described above. It should be noted that the epithelial basement membrane of the early chorionic villi contained both FN (Fig. 1a) and LN (Fig. $1 b$ ), and that the corresponding structure of the term placenta contained LN (Fig. 1d), but not FN (Fig. 1c). 


\section{Summary of the localization of integrin subunits}

The results of the immunofluorescence localization of various integrin subunits (Figs. 2-5) are summarized in Table 1. Since the major difference in the distribution between early and mature chorionic villi has been noticed for FN on the epithelial basement membrane in this and other studies (Kurosawa et al. 1985; Yamaguchi et al. 1985; Yamada et al. 1987), we mainly focalized the localization of various integrin subunits in this structure.

Control sections were not stained to any significant level under the conditions used (Figs. 3c and 5c).

Integrin subunits in early chorionic villi

In the chorionic villi of the early placenta the $\alpha 2$ and $\alpha 6$ subunits were detected on the entire surface of the cytotrophoblasts (Figs. 2b and 2f), but the $\alpha 5$ subunit exhibited the polarized distribution on the basal membrane of the cytotrophoblasts (Fig. 2e), and the $\alpha 3$ subunit was mainly detected on the apical side of the syncytiotrophoblasts (Fig. 2c). The $\alpha 1$ subunit was not detected on the epithelium (Fig. 2a) and the $\alpha 4$ subunit was not detected significantly in any structures of the early chorionic villi (Fig. 2d).

The $\beta 1$ subunit was localized on the basal membrane of the cytotrophoblasts as well as around fetal blood vessels (Fig. 3a). The distribution was similar to that of the $\alpha 5$ subunit (Fig. 2e), suggesting that $\alpha 5 \beta 1$ integrin is expressed on the basal membrane of the early villous cytotrophoblasts. The $\beta 4$ subunit was detected around the cytotrophoblastic cell membrane (Fig. $3 \mathrm{~b}$ ). The colocalization of the $\beta 4$ subunit with $\alpha 2$ and $\alpha 6$ subunits and their distribution suggest that

TABLE 1. Summary of the distribution of integrin subunits in the early and term chorionic villi

\begin{tabular}{|c|c|c|c|c|c|}
\hline \multirow[b]{2}{*}{ Subunit } & \multicolumn{3}{|c|}{ Early } & \multicolumn{2}{|c|}{ Term } \\
\hline & $\begin{array}{c}\text { Cyto- } \\
\text { trophoblast }\end{array}$ & $\begin{array}{l}\text { Syncytio- } \\
\text { trophoblast }\end{array}$ & $\begin{array}{l}\text { Stroma and/or } \\
\text { stromal cells }\end{array}$ & $\begin{array}{l}\text { Syncytio- } \\
\text { trophoblast }\end{array}$ & $\begin{array}{c}\text { Villous } \\
\text { capillary } \\
\text { endothelia }\end{array}$ \\
\hline$\alpha 1$ & - & - & + & - & + \\
\hline$\alpha 2$ & + & - & $(+)$ & + & + \\
\hline$\alpha 3$ & $(+)$ & + & - & + & + \\
\hline$\alpha 4$ & - & - & - & + & + \\
\hline$\alpha 5$ & $+^{*}$ & - & + & - & + \\
\hline$\alpha 6$ & + & - & - & $+^{*}$ & - \\
\hline$\beta 1$ & $+^{*}$ & - & + & + & + \\
\hline$\beta 4$ & + & - & - & $+^{*}$ & - \\
\hline
\end{tabular}

+ , positive immunoreactivity; $(+)$, weakly positive immunoreactivity; -, no immunoreactivity; ${ }^{*}$, basally polarized expression 
either $\alpha 2 \beta 4$ or $\alpha 6 \beta 4$ integrin or both are expressed by the cytotrophoblasts. The syncytiotrophoblasts appeared to express neither of them.

\section{Integrin subunits in mature chorionic villi}

The $\alpha 1$ subunit was detected in the area of fetal blood vessels but not in the epithelium (Fig. 4a). The $\alpha 2, \alpha 3$ and $\alpha 4$ subunits were distributed on both sides of syncytiotrophoblasts as well as in the blood vessel areas (Figs. 4b, 4c and 4d). The $\alpha 5$ subunit was localized mainly on the endothelium and not on the basal surface of the syncytiotrophoblasts (Fig. 4e). In contrast, the $\alpha 6$ subunit was detected almost exclusively on the basal surface of the syncytiotrophoblasts (Fig. 4f).

The $\beta 1$ subunit was detected on both sides of the syncytiotrophoblasts as well as in the area of the fetal blood vessels (Fig. 5a). The $\beta 4$ subunit was detected almost exclusively on the basal surface of the syncytiotrophoblasts (Fig. 5b). The colocalization of the $\beta 4$ subunit with the $\alpha 6$ (Fig. 4f) suggest that the $\alpha 6 \beta 4$ integrin is expressed on the basal membrane of the syncytiotrophoblasts of the mature chorionic villi.

\section{Discussion}

It has been shown that the cell adhesion accompanies the receptor clustering to the basal surface of cells (Cody and Wicha 1986; Dejana et al. 1988; Kowalczyk et al. 1990; Kornberg et al. 1992). Therefore, it seems reasonable to assume that the integrin subunit(s) detected on the basal surface of cells would be involved in the cell adhesion to the basement membrane.

Of the integrin subunits examined in the early placenta, the $\alpha 5$ and $\beta 1$ subunits showed such a polarized distribution as confined to the basal surface, suggesting that $\alpha 5 \beta 1$ integrin is utilized for villous cytotrophoblasts to anchor on the epithelial basement membrane of the early chorionic villi. The $\alpha 5 \beta 1$ integrin is an FN receptor (Springer 1990; Ruoslahti 1991; Yamada 1991) and this observation is compatible with the earlier and present data that $\mathrm{FN}$ is detected on the epithelial basement membrane of the early chorionic villi (Fig. 1a).

The $\alpha 6$ subunit was also detected on the early villous cytotrophoblasts, but its localization around the entire plasma membrane (Fig. 2f) suggests that the $\alpha 6$ $\beta 1 \mathrm{LN}$ receptor (Springer 1990; Ruoslahti 1991; Yamada 1991) is not involved in the cytotrophoblast adhesion to the epithelial basement membrane in spite of the fact that LN is present on this basement membrane (Fig. 1b). However, the present data could not rule out completely the involvement of the $\alpha 6 \beta 1$ integrin in the adhesion to this basement membrane.

Similarly to the $\alpha 6$ subunit, the $\beta 4$ subunit was present around the entire plasma membrane of cytotrophoblastic cells (Fig. $3 \mathrm{~b}$ ). This finding suggests that the $\alpha 6 \beta 4$ integrin expressed by cytotrophoblastic cells is not involved in the attachment of these cells to the epithelial basement mambrane, either. This 
integrin has been reported to be involved in the adhesion of the epithelial cells to the basement membrane in the case of the human skin (Sonnenberg et al. 1991; Giancotti et al. 1992). Indeed, these authors have demonstrated that the $\beta 4$ subunit is localized exclusively to the basal surface of the basal epidermal cells. In the mature chorionic villi, syncytiotrophoblasts appeared not to express the $\alpha 5$ subunit on the basal cell surface (Fig. 4e), suggesting that the $\alpha 5 \beta 1 \mathrm{FN}$ receptor is not involved for these cells to attach to the epithelial basement membrane. This notion is consistent with the observation that the latter membrane lacked FN (Fig. 1c).

Instead, syncytiotrophoblasts expressed the $\alpha 6 \beta 4$ integrin on the basal cell surface (Figs. $4 \mathrm{f}$ and $5 \mathrm{~b}$ ) and therefore, these cells probably utilize this integrin for their attachment to the epithelial basement membrane of the mature placental villi as in the case of the human skin (Sonnenberg et al. 1991; Giancotti et al. 1992). This integrin has been suggested to be an LN receptor, although no definitive conclusion has been drawn yet (Lots et al. 1990; Sonnenberg et al. 1991; Giancotti et al. 1992; Lee et al. 1992). The localization of LN (Fig. 1d) is consistent with this idea.

The $\alpha 5$ subunit was detected in the areas of blood vessels of both early and term chorionic villi (Figs. 2e and 4e). These findings are consistent with those that the endothelial basement membrane contained FN (Figs. 1a and 1c). It appears likely that the endothelial cells make use of the $\alpha 5 \beta 1 \mathrm{FN}$ receptor for attachment to this basement membrane, since the $\beta 1$ subunit was also detected on these cells (Fig. 3a and 5a). It is also possible that the endothelial cells of the term villi may use the $\alpha 1 \beta 1, \alpha 2 \beta 1, \alpha 3 \beta 1$ or $\alpha 4 \beta 1$ intergin for their attachment to this strucuture.

Although the endothelial basement membrane in the term chorionic villi contained LN (Fig. 1d), the $\alpha 6 \beta 1 \mathrm{LN}$ receptor appeared not to be involved in the attachment of the endothelial cells to this basement membrane, since the $\alpha 6$ subunit was not detected on these cells (Fig. 4f).

Recently, an investigation similar to the present work has been reported by Korhonen et al. (1991). These authors, however, failed to detect the $\alpha 5$ subunit in any structure. Their result seems to be inconsistent with the fact that the $\alpha 5$ $\beta 1$ integrin can be isolated from the placenta (Pytela et al. 1978). Moreover, they demonstrated the basally polarized distribution of the $\beta 1$ subunit on the mature villous trophoblast, while this subunit was detected at the apical pole of the trophoblast by De Strooper et al. (1989). These differences may be due to the difference in the antibodies used.

Thus, the present work supports the idea that the cells express, when required, the integrin(s) specific for the extracellular matrix component leading to the proper tissue organization. 


\section{Acknowledgment}

This work was supported in part by a Grant-in-Aid from the Ministry of Education, Science and Culture of Japan, and by Special Coordination Funds of the Science and Technology Agency of the Japanese Government.

\section{References}

1) Cody, R.L. \& Wicha, M.S. (1986) Clustering of cell surface laminin enhances its association with the cytoskeleton. Exp. Cell Res., 165, 107-116.

2) De Strooper, B., Van der Schueren, B., Jaspers, M., Saison, M., Spaepen, M., Van Leuven, F., Van den Berghe, H., \& Cassiman, J.-J. (1989) Distribution of the $\beta 1$ subunit of the integrins in human cells and tissues. J. Histochem. Cytochem., 37, 299307.

3) Dejana, E., Colella, S., Conforti, G., Abbadini, M., Gaboli, M., \& Marchisio, P.C. (1988) Fibronectin and vitronectin regulate the organization of their respective Arg-Gly-Asp adhesion receptors in cultured human endothelial cells. J. Cell Biol., 107, 1215-1223.

4) Giancotti, F.G., Stepp, M.A., Suzuki, S., Engvall, E., \& Ruoslahti, E. (1992) Proteolytic processing of endogenous and recombinant $\beta 4$ integrin subunit. J. Cell Biol., 118, 951-959.

5) Hynes, R.O. (1981) Fibronectin and its relation to cellular structure and behavior. In: Cell Biology of Extracellular Matrix, Plenum Pub. Corp., New York, pp. 295-334.

6) Hynes, R.O. (1987) Integrins: A family of cell surface receptors. Cell, 48, 549-554.

7) Korhonen, M., Ylänne, J., Laitinen, L., Cooper, H.M., Quaranta, V., \& Virtanen, I. (1991) Distribution of the $\alpha 1-\alpha 6$ integrin subunits in human developing and term placenta. Lab. Invest., 65, 347-456.

8) Kornberg, L., Earp, H.S., Parsons, J.T., Schaller, M., \& Juliano, R.L. (1992) Cell adhesion of integrin clustering increases phosphorylation of a focal adhesionassociated tyrosine kinase. J. Biol. Chem., 267, 23439-23442.

9) Kowalczyk, A.P., Tulloh, R.H., \& McKeown-Longo, P.J. (1990) Polarized fibronectin secretion and localized matrix assembly sites correlate with subendothelial matrix formation. Blood, 75, 2335-2342.

10) Kurosawa, K., Isemura, M., Yamaguchi, Y., Yosizawa, Z., Furuyama, T., Yoshinaga, K., \& Ishii, T. (1985) Change in distribution of connective tissue components of human placentae with maturation. Tohoku J. Exp. Med., 147, 261-265.

11) Lee, E., Lotz, M., Steele, G. J., \& Mercurio, A. (1992) The integrin $\alpha 6 \beta 4$ is a laminin receptor. J. Cell Biol., 117, 671-678.

12) Lots, M.M., Korzelius, C.A. \& Mercurio, A.M. (1990) Human colon carcinoma cell use multiple receptors to adhere to laminin: Involvement of $\alpha 6 \beta 4$ and $\alpha 2 \beta 1$ integrins. Cell Reg., 1, 249-257.

13) Martin, G.R. \& Timpl, R. (1987) Laminin and other basement membrane components. Annu. Rev. Cell Biol., 3, 57-85.

14) Pytela, R., Pierschbacher, M.D., Argraves, S., Suzuki, S. \& Ruoslahti, E. (1987) Arginine-glycine-aspartic acid adhesion receptor. Methods Enzymol., 144, 475-489.

15) Ruoslahti, E. (1988) Fibronectin and its receptors. Annu. Rev. Biochem., 57, 375413.

16) Ruoslahti, E. (1991) Integrins. J. Clin. Invest., 87, 1-5.

17) Sonnenberg, A., Calafat, J., Janssen, H., Daams, H., van der Raaij-Helmer, L.M.H., Falcioni, R., Kennel, S.J., Aplin, J.D., Baker, J., Loizidou, M., \& Garrod, D. (1991) Integrin $\alpha 6 / \beta 4$ complex is located in hemidesmosomes, suggesting a major role in epidermal cell-basement membrane adhesion. J. Cell Biol., 113, 907-917. 
18) Springer, T.A. (1990) Adhesion receptors of the immune system. Nature, 346, 425434.

19) Yamada, K.M. (1991) Adhesive recognition sequences. J. Biol. Chem., 1280912812.

20) Yamada, T., Isemura, M., Yamaguchi, Y., Munakata, H., Hayashi, N., \& Kyogoku, M. (1987) Immunohistochemical localization of fibronectin in the human placentas at their different stages of maturation. Histochemistry, 86, 579-584.

21) Yamaguchi, Y., Isemura, M., Yosizawa, Z., Kurosawa, K., Yoshinaga, K., Sato, A., \& Suzuki, M. (1985) Changes in the distribution of fibronectin in the placenta during normal human pregnancy. Am. J. Obestet. Gynecol., 152, 715-718. 
Fig. 1. Immunoperoxidase staining of sections from the human placenta at 6-week's gestation ( $a$ and $b$ ) and from the term placenta ( $c$ and $d$ ) for fibronectin ( $a$ and $c)$ and laminin $(b$ and $d)$. Note that the trophoblastic basement membranes in the early chorionic villi are positive for both fibronectin (a) and laminin (b) and that those in the term villi are positive for laminin but negative for fibronectin (arrows). Fetal blood vessels in the term villi are positive for both fibronectin and laminin (arrow heads). ( $a$ and $b$, $\times 250 ; \mathrm{c}$ and $\mathrm{d}, \times 1,000)$ 


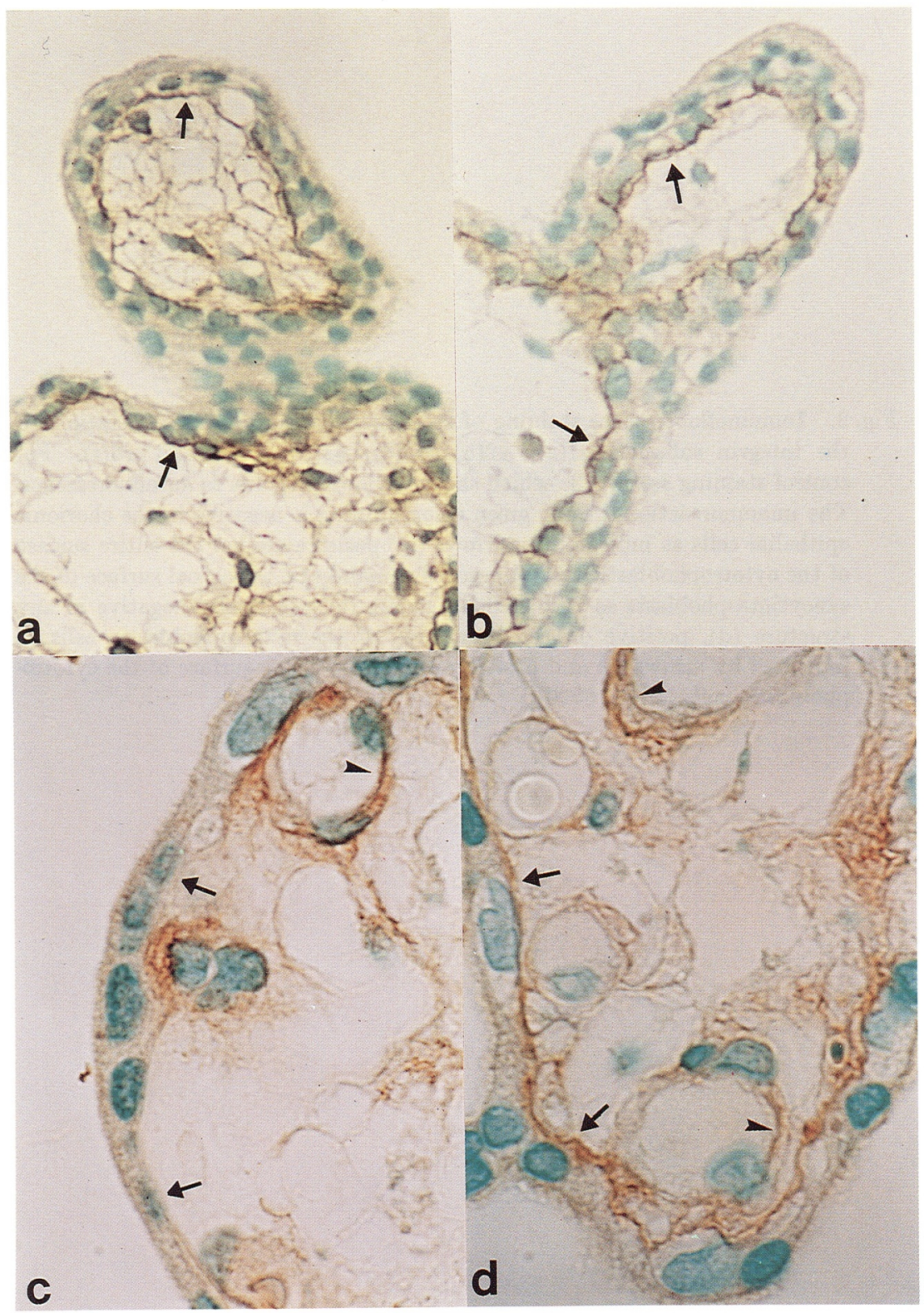


Fig. 2. Immunofluorescence staining of sections from the 10-week's gestation for the integrin subunits $\alpha 1(\mathrm{a}), \alpha 2(\mathrm{~b}), \alpha 3(\mathrm{c}), \alpha 4(\mathrm{~d}), \alpha 5(\mathrm{e})$ and $\alpha 6(\mathrm{f})$. For control staining see Fig. $3 \mathrm{c}$ which shows yellow color due to autofluorescence. The immunoreaction-specific green color staining is negative in the chorionic epithelial cells as indicated by arrows (a); positive around the entire surface of the cytotrophoblastic cells (b), positive mainly on the apical surface of the syncytiotrophoblasts as indicated by arrows (c), practically negative in any structure (d), positive on the basal side of the cytotrophoblastic cells as indicated by arrows (e) and positive around the entire surface of the cytotrophoblastic cells $(\mathrm{f}) . \quad(\times 250)$ 


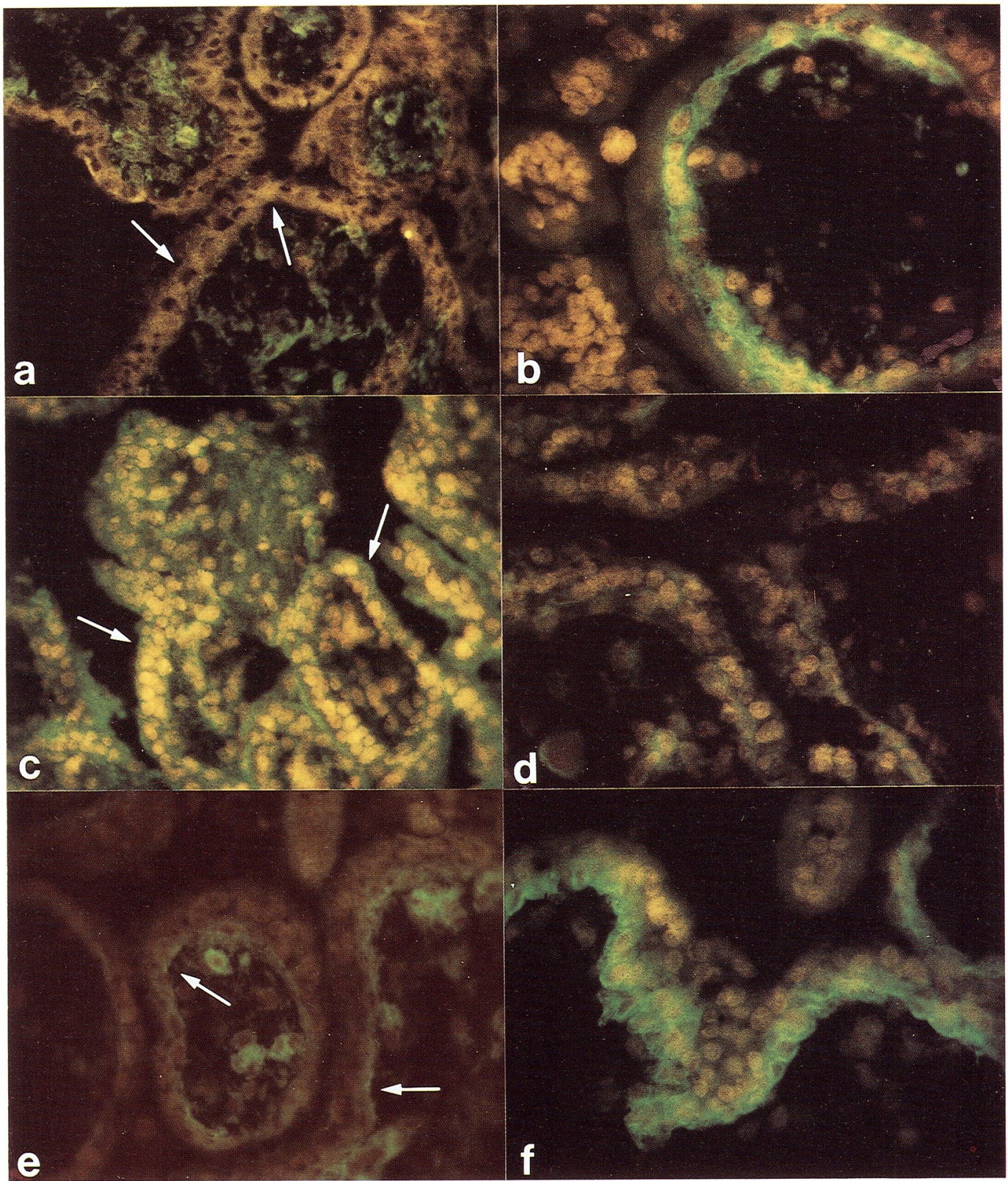


Fig. 3. Immunofluorescence staining of sections from the placenta at 10-week's gestation for integrin subunits $\beta 1(\mathrm{a})$ and $\beta 4(\mathrm{~b})$. Control staining is shown in (c). Positive staining is seen on the basal surface of the cytotrophoblastic cells in (a) and around their entire surface in (b). Some of the cells in the stromal core are positive for the $\beta 1$ subunit $(\mathrm{a}) . \quad(\mathrm{a}, \times 250 ; \mathrm{b}$ and $\mathrm{c}, \times 400)$ 


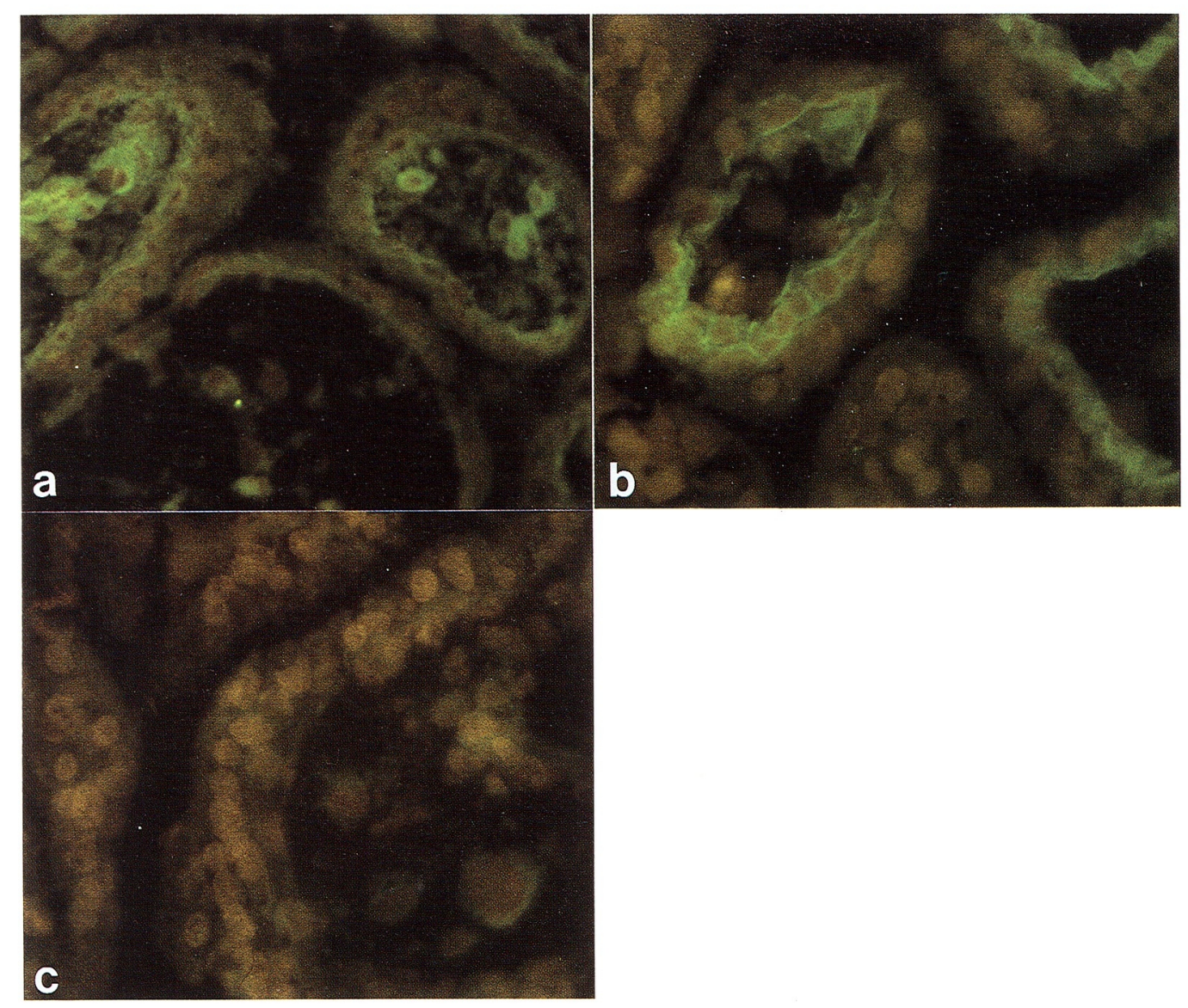


Fig. 4. Immunofluorescence staining of sections from the term placenta for integrin subunits $\alpha 1(\mathrm{a}), \alpha 2(\mathrm{~b}), \alpha 3(\mathrm{c}), \alpha 4(\mathrm{~d}), \alpha 5(\mathrm{e})$ and $\alpha 6(\mathrm{f})$. Positive staining is seen around the fetal blood vessels but not on the syncytiotrophoblasts (a), on both basal and apical surfaces of the syncytiotrophoblasts as indicated by arrows as well as in the areas of fetal blood vessels (b, c and d), mainly around the fetal blood vessels (e) and on the basal surface of the syncytiotrophoblasts (f). Note that the $\alpha 5$ subunit is not present on the basal surface of the syncytiotrophoblasts as indicated by arrows (e). (a, b, d and e, $\times 250$; $\mathrm{c}$ and $\mathrm{e}, \times 400)$ 


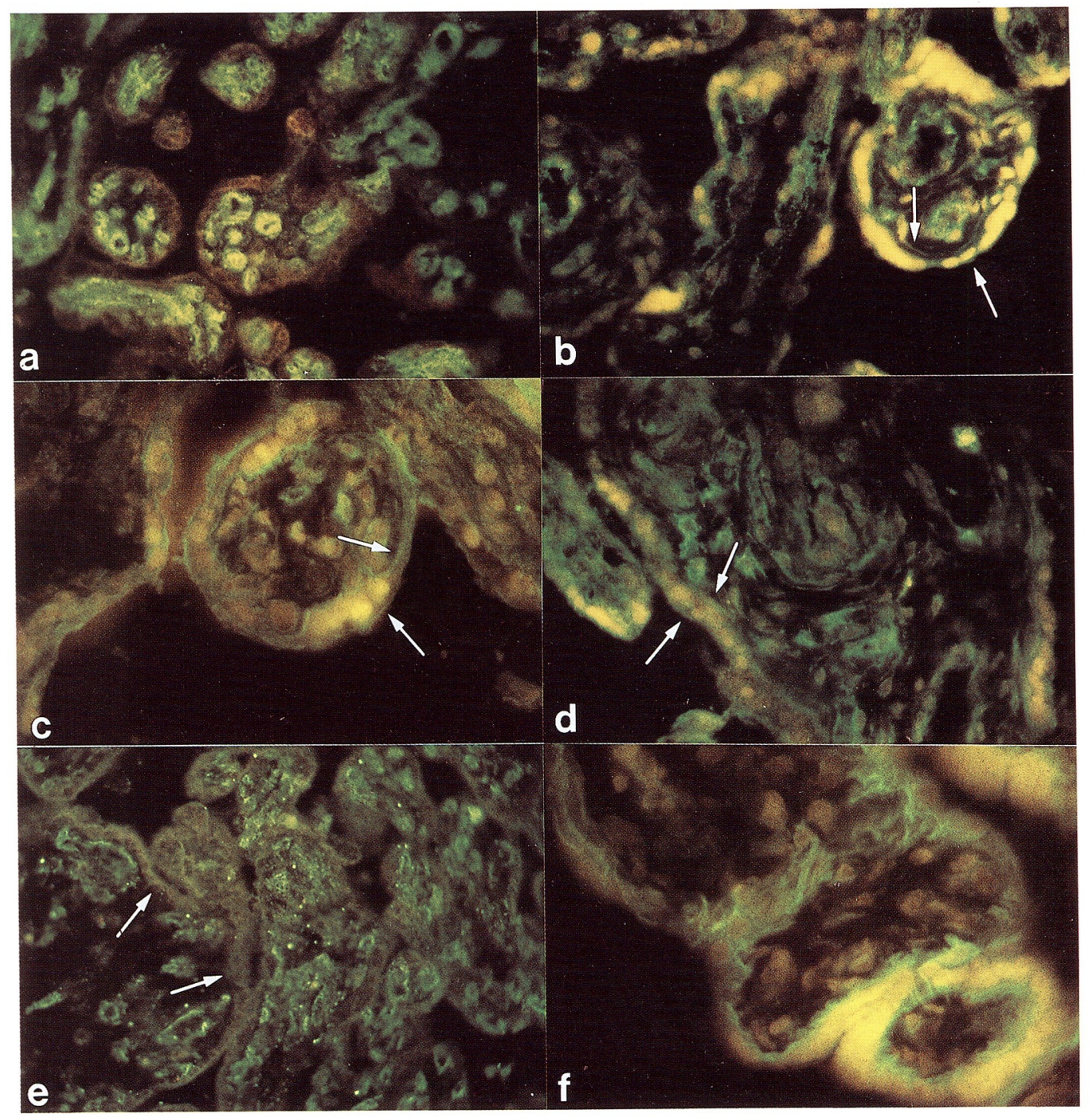


Fig. 5. Immunofluorescence staining of sections from the term placenta for integrin subunits $\beta 1(a)$ and $\beta 4(b)$. Control staining is shown in (c). The $\beta 1$ subunit is present on both apical and basal surfaces of the syncytiotrophoblasts and around the fetal blood vessels (a). In contrast, the $\beta 4$ subunit is restricted to the basal surface of syncytiotrophoblasts. $(a, \times 250 ; b$ and $c$, $\times 400)$ 


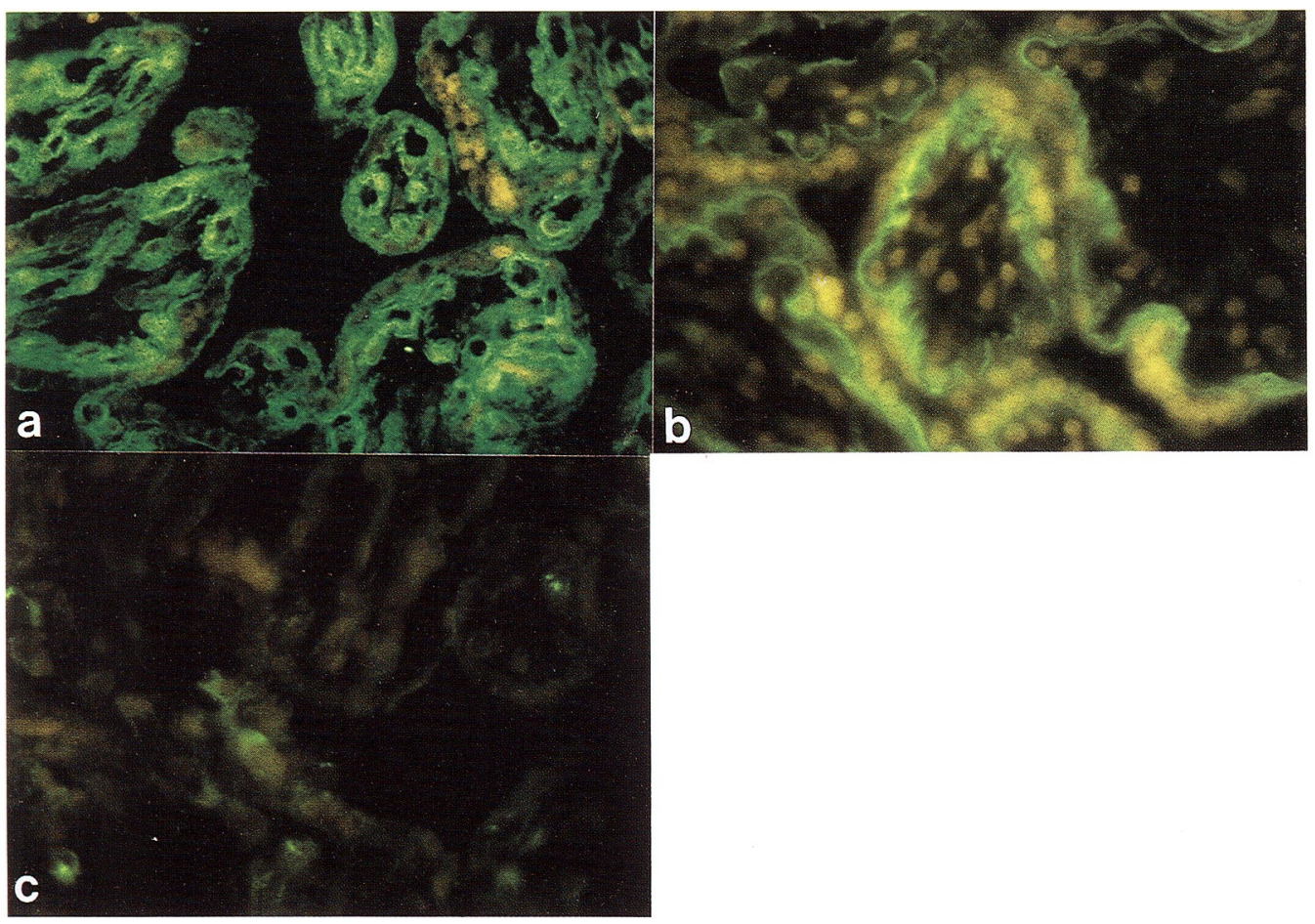

